\title{
Diversities in perceived knowledge and practice of preoperative skin preparation in Swedish orthopaedic surgery
}

Ida Markström and Kristofer Bjerså

The self-archived postprint version of this journal article is available at Linköping University Institutional Repository (DiVA):

http:/ / urn.kb.se/ resolve?urn=urn:nbn:se:liu:diva- 127375

N.B.: When citing this work, cite the original publication.

Markström, I, Bjerså, K., (2015), Diversities in perceived knowledge and practice of preoperative skin preparation in Swedish orthopaedic surgery., J ournal of perioperative practice, 25(5), 101-106.

DOI: https:// doi.org/ 10.1177/ 175045891502500502

Original publication available at:

Copyright: SAGE Publications (UK and US)

http:// www.uk.sagepub.com/ home.nav 
Diversities in Perceived Knowledge and Practice of Preoperative Skin Preparation in Swedish Orthopaedic Surgery

\section{Running title: Preoperative Skin Preparation}

Authors: Ida Markström ${ }^{1}$ ORN, RN, MSc, Kristofer Bjerså2,3 CNS, RN, PhD

${ }^{1}$ Department of Anesthesia and Intensive Care, Sinnescentrum, Vrinnevi Hospital, Norrköping, Sweden

${ }^{2}$ Division of Nursing, Department of Neurobiology, Care Sciences and Society, Karolinska Institutet, Stockholm, Sweden.

${ }^{3}$ Division of Nursing Science, Department of Medical and Health Sciences, Linköping University, Linköping, Sweden

Corresponding author:

Ida Markström

Department of Anesthesia and Intensive Care, Sinnescentrum, Vrinnevi Hospital 60379 Norrköping

Sweden

Phone: 0046-(0)730-212081

Fax: 010-10423 50

E-mail: ida.markstrom@lio.se 


\section{Abstract}

Preoperative skin preparations may reduce the risk of hospital-acquired infections. This cross sectional questionnaire study aimed to identify the practice and knowledge of preoperative skin preparation in Swedish orthopaedic surgery departments. 106 respondents (RR 68\%) from 13 Swedish orthopaedic departments reported a diversity of current recommendations and evidence, and good knowledge of skin preparations. This study found variations in practice and deviations from recommendations, despite high levels of knowledge.

Key words: Disinfection, skin preparation, orthopaedic, clorhexidine gluconate, Perioperative nursing

\section{Introduction}

Hospital-acquired infection is associated with significantly increased patient suffering, morbidity and mortality (De Lissovoy, Fraeman, Hutchins, Murphy, Song \& Vaughn, 2009; Whitehouse, Friedman, Kirkland, Richardson \& Sexton, 2002; Mangram, Horan, Pearson, Silver \& Jarvis, 1999; Ponds de Leon, 1991), prolonged hospital stays and higher health care costs (Jenks, Laurent, McQuarry \& Watkins, 2014; Humphreys, 2009; Klevens et al., 2007; Kirkland, Briggs, Triwett, Wilkingsson, \& Sexton, 1999; Pittet, Taraara \&Wenzel, 1994). Hospital-acquired infection after orthopaedic surgery may have severe consequences, such as prolonged hospital stays and additional surgery (Darouiche, 2004; Whitehouse, Friedman, Kirkland, Richardson \& Sexton, 2002). Infections after orthopaedic surgery also cause substantially greater physical limitations and decreased health related quality of life (Whitehouse, Friedman, Kirkland, Richardson \& Sexton, 2002). 
In surgical care, wounds are one risk factor in the development of hospital-acquired infections, and microbes on the skin at the time of surgery elevate that risk (Kamel et al., 2013; Veiga et al., 2009; Krizek \& Robson, 1975). Previous studies have discussed the role of preoperative skin antisepsis in reducing the risk of hospital-acquired infection, but there is still debate about evidence that supports this hypothesis (Webster \& Osborne, 2007; Grabsch, Mitchell, Hooper, Turnidge, 2004; Hibbard, Mulberry \& Brady, 2002; Mangram et al., 1999). However, the current consensus is that the goal of applying preoperative skin antisepsis is to reduce the microbial burden on the surface of the skin to sub-pathogenic levels before surgical incision (Webster \& Osborne, 2008; Digison, 2007; Mangram et al., 1999;). Despite a lack of evidence to support this practice, skin cleansing with an antiseptic solution has become a preoperative routine in operating rooms (OR) globally (Derde, 2012; Koburger, 2010; Kaiser 1988).

Preoperative antiseptic showering is also widely practised and accepted as an additional preventive intervention for hospital-acquired infection in surgical care (Webster \& Osborne, 2012; Edminston et al., 2008). Preoperative antiseptic showering is thought to reduce microbes on the skin before the patient enters the OR but is not perceived to be a replacement for the perioperative skin preparation performed directly prior to the surgical incision (Edministon, 2010). In Sweden, three to five preoperative showers with chlorhexidine gluconate are recommended for patients undergoing elective surgery (Socialstyrelsen, 2006).

A third antiseptic procedure prior to surgical incision in Swedish surgical departments has also come to our knowledge, that is, skin cleansing with chlorhexidine gluconate in the OR prior to skin disinfection with an antiseptic solution. As far as we know, no previous research has been published to support this practice. There are two manufacturers of chlorhexidine gluconate in Sweden, both recommending a careful rinse with water after applying the soap 
solution to the body and hair (Fresenius Kabi, 2013; Mölnlycke healthcare, 2013), see Fact

Box 1. When chlorhexidine gluconate is used in the OR, difficulties in acting on these recommendations, such as careful rinsing, might be challenging or the procedure may even be neglected.

Considering these three procedures, the recommendations and the lack of knowledge of current practice in Sweden, this study set a goal to identify preoperative procedures for skin preparation and to investigate the knowledge of skin preparations among personnel at Swedish orthopaedic surgery departments.

\section{Whole body wash with HiBiScrub®}

1. Wash face with undiluted HiBiScrub Plus, especially around the nose, avoiding eyes and ears. For each wash, use approximately $25 \mathrm{ml}$ - that is, $50 \mathrm{ml}$ per shower. Local instruction variations may occur.

2. Use a clean sponge, working downwards, wash armpits.

3. Continue washing downwards and wash well around the groin area.

4. After washing all these important areas, rinse off under the shower.

5. Now repeat steps 1 to 4 , but this time starting with hair.

6. After a final rinse, dry thoroughly with a clean towel and put on clean clothes.

Mölnlycke healthcare, 2014

\section{Washing instructions for Descutan ${ }^{\circledR}$ wash sponge (double shower)}

1. Shower whole body, including hair, with water. Turn off the shower.

2. Wash hair with soap solution in the bag.

3. Open the sponge package and fill with water to moisten the sponge. Wash body with the sponge.

4. Wash face, be careful around the nose.

5. Wash torso and pay special attention to armpits and navel. Wash lower trunk, legs and feet with special attention to genitals and groin.

6. Rinse whole body with water, turn off the shower.

7. Take a new sponge and soap solution and repeat the entire wash.

8. Dry the body with a clean towel, put on clean clothes.

Fresenius Kabi, 2014

Fact Box 1. Manufacturers' recommendation for use of chlorhexidine gluconate 


\section{Methods}

A cross sectional, paper questionnaire study design was used in this descriptive study.

\section{Sample and data collection}

A strategic selection of ORs in Swedish orthopaedic surgery departments was approached for participation during the spring of 2013. Selection was based on national geographical representation, department size and hospital size. Head nurses from 23 departments were contacted by email and asked for approval of questionnaire distribution to employees. Fifteen departments approved participation. They were then asked for the number of employees that could be related to the aim of the study and be assigned a questionnaire. The number of questionnaires specified was sent by regular mail to the head nurse, who distributed them. In total, 156 questionnaires were administered. Questionnaires were returned in an envelope sent with the questionnaires. Reminders of participation were sent to the head nurse two and four weeks after the initial administration. A total of 106 questionnaires from 13 departments were returned and analysed, representing a response rate of $68 \%$.

\section{Questionnaire}

A paper questionnaire was compiled that was inspired by a previous Master thesis (Johansson \& Björk, 2011). Both open and closed response alternatives were used. The first part of the questionnaire included demographic data, such as age, sex, education and work experience. The second part consisted of eight questions that examined regular hygiene routines (not reported in this article). The third part consisted of five statements and questions about skin preparation. The fourth part consisted of 14 questions about skin preparation methods and techniques at the particular department. 


\section{Analysis}

Data were compiled in IBM SPSS version 20 and presented in absolute and relative frequencies, mean and standard deviation (SD). Data are presented with text and tables.

\section{Ethics}

This study was conducted as a part of a Master thesis project in nursing science. The ethics were reviewed, monitored and approved by the University of Linköping in accordance with Swedish law on ethics in research (Prop.2007/08:44; Law 2003:460). All participation in this study in terms of completing and returning the questionnaire was voluntary, and all data were collected anonymously. The results are presented on the group level.

\section{Results}

Respondents' demographics showed that $90 \%(n=95)$ were women and that the mean age was 57.6 years $(\mathrm{SD}=8.6)$. Education levels and specialities among nurse participants varied; $59 \%$ $(n=63)$ were OR nurses, $3 \%(n=3)$ were general registered nurses and $2 \%(n=2)$ were anaesthetics nurses. Additional health care professions among the participants were $29 \%$ nurse assistants $(n=31)$ and $5 \%(n=7)$ surgery assistants. The mean time in the current profession at the time was 20 years $(\mathrm{SD}=12.5)$.

\section{Skin preparation practice}

Preoperative shower before arrival at the OR was standard practice at all participating surgical departments, with a frequency of two or more showers. Two respondents reported using general soap without disinfection properties; all others reported using products containing chlorhexidine. 
Respondents from all of the 13 departments claimed that they used chlorhexidine gluconate for perioperative skin disinfection in the OR. Additional chlorhexidine gluconate cleansing was used in the perioperative skin preparation in all of the surgical departments that responded, and $95 \%(n=101 / 104)$ of the respondents described practicing this procedure, see Table 1. Respondents from barely half of the participating departments $(46 \%, n=6 / 13)$ described different methods, although they worked in the same unit. One respondent reported a procedure with chlorhexidine gluconate that complied with the manufacturer's recommendations. Three fourths $(76 \% ; n=59 / 106)$ of the participants claimed to be familiar with manufacturers' recommendations. An essential part of the recommendations of the manufacturer was to rinse with water after chlorhexidine gluconate was applied, which $21 \%$ $(n=21 / 102)$ of the respondents stated in their description. $39 \%(n=41 / 104)$ of the respondents claimed that they used chlorhexidine gluconate in the OR before both elective and acute surgical operations. 
Table 1 Perioperative washing with clorhexidine gluconate in the operating room

\begin{tabular}{|c|c|c|c|c|c|c|c|c|c|c|c|}
\hline $\mathrm{n}=102$ & Step 1 & & Step 2 & & Step 3 & & Step 4 & & Step 5 & & Step 6 \\
\hline 17 & Add water & $\rightarrow$ & Cleansing & $\rightarrow$ & $\begin{array}{c}\text { Allow } \\
\text { solution to } \\
\text { dry }\end{array}$ & & & & & & \\
\hline 15 & Add water & & Cleansing & & $\begin{array}{l}\text { Wipe off with } \\
\text { paper }\end{array}$ & & & & & & \\
\hline 1 & Add water & $\rightarrow$ & Cleansing & $\rightarrow$ & $\begin{array}{l}\text { Rinse with } \\
\text { water }\end{array}$ & $\rightarrow$ & $\begin{array}{l}\text { Wipe off with } \\
\text { paper }\end{array}$ & & & & \\
\hline 1 & Add water & $\rightarrow$ & Cleansing & $\rightarrow$ & $\begin{array}{l}\text { Rinse with } \\
\mathrm{NaCl}\end{array}$ & $\rightarrow$ & $\begin{array}{c}\text { Wipe off with } \\
\text { paper }\end{array}$ & & & & \\
\hline 5 & Add $\mathrm{NaCl}$ & $\rightarrow$ & Cleansing & $\rightarrow$ & $\begin{array}{c}\text { Allow } \\
\text { solution to } \\
\text { dry }\end{array}$ & & & & & & \\
\hline 1 & Add water & $\rightarrow$ & Cleansing & $\rightarrow$ & $\begin{array}{l}\text { Wait for } 1 \\
\text { minute }\end{array}$ & $\rightarrow$ & $\begin{array}{c}\text { Sometime let } \\
\text { solution dry/ } \\
\text { sometimes } \\
\text { wipe off with } \\
\text { paper } \\
\end{array}$ & & & & \\
\hline 2 & Add water & $\rightarrow$ & Cleansing & $\rightarrow$ & $\begin{array}{l}\text { Wait for } 1 \\
\text { minute }\end{array}$ & $\rightarrow$ & $\begin{array}{l}\text { Wipe off } \\
\text { with paper }\end{array}$ & & & & \\
\hline 1 & Add water & $\rightarrow$ & Cleansing & $\rightarrow$ & $\begin{array}{c}\text { Wait for } 1 \\
\text { minute }\end{array}$ & $\rightarrow$ & $\begin{array}{c}\text { Rinse with } \\
\text { water }\end{array}$ & $\rightarrow$ & $\begin{array}{c}\text { Wipe off } \\
\text { with paper }\end{array}$ & & \\
\hline 6 & Adds water & $\rightarrow$ & Cleansing & $\rightarrow$ & $\begin{array}{l}\text { Wait for } 1 \\
\text { minute }\end{array}$ & $\rightarrow$ & $\begin{array}{l}\text { Wipe off with } \\
\text { paper }\end{array}$ & $\rightarrow$ & $\begin{array}{l}\text { Wait for } 1 \\
\text { minute }\end{array}$ & $\rightarrow$ & $\begin{array}{l}\text { Repeats } \\
\text { process from } \\
\text { the beginning }\end{array}$ \\
\hline 9 & Add water & $\rightarrow$ & Cleansing & $\rightarrow$ & $\begin{array}{l}\text { Wait for 2-5 } \\
\text { minutes }\end{array}$ & $\rightarrow$ & $\begin{array}{l}\text { Wipe off with } \\
\text { paper }\end{array}$ & & & & \\
\hline 12 & Add water & $\rightarrow$ & Cleansing & $\rightarrow$ & $\begin{array}{l}\text { Wait for } 2-5 \\
\text { minutes }\end{array}$ & $\rightarrow$ & $\begin{array}{l}\text { Rinse with } \\
\text { water }\end{array}$ & $\rightarrow$ & $\begin{array}{c}\text { Wipe off } \\
\text { with paper }\end{array}$ & & \\
\hline 4 & Add water & $\rightarrow$ & Cleansing & $\rightarrow$ & $\begin{array}{l}\text { Wait for 2-5 } \\
\text { minutes }\end{array}$ & $\rightarrow$ & $\begin{array}{c}\text { Allow } \\
\text { solution to } \\
\text { dry }\end{array}$ & & & & \\
\hline 16 & Add water & $\rightarrow$ & $\begin{array}{l}\text { Cleansing for } \\
\text { at least } 3 \\
\text { minutes }\end{array}$ & $\rightarrow$ & $\begin{array}{l}\text { Wipe off with } \\
\text { paper }\end{array}$ & & & & & & \\
\hline 1 & Add water & $\rightarrow$ & $\begin{array}{l}\text { Cleansing for } \\
\text { at least } 3 \\
\text { minutes }\end{array}$ & $\rightarrow$ & $\begin{array}{l}\text { Wait for } 3 \\
\text { minutes }\end{array}$ & $\rightarrow$ & $\begin{array}{l}\text { Wipe off with } \\
\text { paper }\end{array}$ & & & & \\
\hline 2 & Add water & $\rightarrow$ & $\begin{array}{l}\text { Cleansing for } \\
\text { at least } 3 \\
\text { minutes }\end{array}$ & $\rightarrow$ & $\begin{array}{l}\text { Rinse with } \\
\text { water }\end{array}$ & $\rightarrow$ & $\begin{array}{l}\text { Wipe off with } \\
\text { paper }\end{array}$ & & & & \\
\hline 5 & Add water & $\rightarrow$ & $\begin{array}{l}\text { Cleansing for } \\
\text { at least } 5 \\
\text { minutes } \\
\end{array}$ & $\rightarrow$ & $\begin{array}{l}\text { Sometimes } \\
\text { rinse with } \\
\text { water }\end{array}$ & $\rightarrow$ & $\begin{array}{l}\text { Wipe off with } \\
\text { paper }\end{array}$ & & & & \\
\hline 3 & Add water & $\rightarrow$ & $\begin{array}{c}\text { Cleansing for } \\
\text { at least } 3 \\
\text { minutes } \\
\end{array}$ & $\rightarrow$ & $\begin{array}{c}\text { Allow } \\
\text { solution to } \\
\text { dry }\end{array}$ & & & & & & \\
\hline 1 & Add water & $\rightarrow$ & $\begin{array}{l}\text { Cleaning for } 6 \\
\text { minutes }\end{array}$ & $\rightarrow$ & $\begin{array}{l}\text { Wait for } 5 \\
\text { minutes }\end{array}$ & $\rightarrow$ & $\begin{array}{l}\text { Wipe off with } \\
\text { paper }\end{array}$ & & & & \\
\hline
\end{tabular}

\section{Knowledge of skin preparation routines}

Responses to the five skin preparation specific statements are reported in Table 2. A majority of the participants $(62 \% ; n=63)$ correctly responded that the skin never becomes sterilised by skin disinfection, $54 \%(n=57)$ that chlorhexidine has a cumulative effect, $34 \%(n=35)$ that 
chlorhexidine disinfection decreases the number of bacteria up to five times, $40 \%(n=42)$ that chlorhexidine gluconate should be rinsed off only with water, and $56 \%(n=57)$ that the time allowed for the drying of chlorhexidene is essential regardless of the length of time during which the application is given. Five respondents gave correct answers to all of the statements. The remaining respondents gave one or more incorrect answers.

Table 2. Response to statements about skin preparation

\begin{tabular}{|l|c|c|c|c|}
\hline & Fully agree & Partly agree & Disagree & $\begin{array}{l}\text { No } \\
\text { opinion }\end{array}$ \\
\hline $\begin{array}{l}\text { The skin becomes sterilized by using skin } \\
\text { disinfection (n=102) }\end{array}$ & $11 \%$ & $26 \%$ & $62 \%$ & $1 \%$ \\
\hline $\begin{array}{l}\text { Clorhexidine has a cumulative effect, meaning } \\
\text { that repeated disinfection with clorhexidine } \\
\text { gluconate will decrease the resident skin } \\
\text { pathogens more and more each time (n=105) }\end{array}$ & $54 \%$ & $28 \%$ & $9 \%$ & $9 \%$ \\
\hline $\begin{array}{l}\text { It is possible to repeat clorhexidine disinfection } \\
\text { up to five times and decrease number of } \\
\text { bacteria each time (n=104) }\end{array}$ & $34 \%$ & $18 \%$ & $16 \%$ & $32 \%$ \\
\hline $\begin{array}{l}\text { Clorhexidine gluconate can be both rinsed off } \\
\text { with water and be dried off with paper towels } \\
\text { (n=106) }\end{array}$ & $33 \%$ & $20 \%$ & $40 \%$ & $7 \%$ \\
\hline $\begin{array}{l}\text { The drying time is not essential if clorhexidine } \\
\text { is applied over a period of two minutes (n=102) }\end{array}$ & $12 \%$ & $12 \%$ & $56 \%$ & $20 \%$ \\
\hline
\end{tabular}




\section{Discussion}

The struggle to eliminate hospital-acquired infections is a constantly ongoing process among OR staff, especially for those working with high-risk surgery such as orthopaedics. This study aimed to identify the usage of skin preparation procedures prior to surgery and investigate the knowledge of skin preparations among personnel at Swedish orthopaedic surgery departments. Differences between the respondents in all of these areas were found.

All of the participating departments followed the prescriptions of the National Board of Health and Welfare, which recommends three to five showers before surgery (Socialstyrelsen, 2006). Two or more preoperative showers with clorhexidine gluconate were standard practice in all the departments investigated. However, two participants reported using general, nondisinfecting soap. The primary study showed that washing with soap and water and towel drying has a significant disruptive effect on the skin's barrier function (Voegeli, 2008), which in this setting seems contradictory to the purpose.

The results show that perioperative cleaning with clorhexidine gluconate indeed exists; respondents from all 13 departments confirmed that. The practice may be followed due to a misunderstanding of the current recommendation of three to five double showers with clorhexidine gluconate before surgery. This incorrect conception could derive from the belief that three showers are accomplished if patients are given a shower the night before, the same morning and in the OR. In existing reviews of how to perform safe skin preparation, no recommendations or guidelines for such perioperative practices with chlorhexidine gluconate have been found (Mangram et al., 1999; Webster \& Osborne, 2006); World Health Organization, 2002; Association of Perioperative Registered Nurses, 1996). This lack of investigation into and discussion of the practice of perioperative chlorhexidine gluconate 
cleansing calls for further research to investigate the distribution and benefits of such practices. Evidence-based learning must impregnate all care to provide patient safety (International Council of Nurses, 2012). The economic perspective must also be discussed, as costs for products and staff must be taken into consideration.

Varying interpretations of procedures in the usage of chlorhexidine gluconate were found, despite the fact that $76 \%$ of the respondents claimed to be familiar with manufacturers' recommendations. As shown in Table 2, 53\% assumed that it does not matter whether the soap solution is wiped off with paper/towel or rinsed off with water. Half of the respondent group (51/102) did not rinse with water after cleaning with the sponge, while 17 respondents allowed the solution to dry on the skin. In addition, 38 respondents applied the solution and then waited one to six minutes before wiping or rinsing with water or just let it dry on the skin. There were 28 respondents that described cleaning with the sponge for three to six minutes before wiping it off or rinsing with water. Another six respondents claimed to follow the whole procedure twice before disinfecting the skin. As described in Fact Box 1, there is no mention of the duration of time needed for cleansing in the instructions for chlorhexidine gluconate use (Fresenius Kabi, 2013; Mölnlycke healthcare, 2013). However, the six respondents who reported two perioperative chlorhexidine gluconate cleanings in the OR may have assumed that they accomplished the five recommended showers with chlorhexidine gluconate.

A lack of knowledge concerning skin preparation procedures was also identified. Current evidence supports a cumulative effect of chlorhexidine, meaning that the number of bacteria is reduced at each application of chlorhexidine and continues to decrease during up to five disinfective procedure rounds (Lowbury, Lilly \& Bull, 1960; Brandberg, 1989; Lilly, Lowbury \& Wilkins, 1979). The cumulative effect of chlorhexidine was unknown to $48 \%$ of 
respondents in this study. It is essential that health care staff deliver care based on evidence and critical thinking (Hockenberry, Walden, Brown \& Barrera, 2007). Hence, this finding indicates a need of educational interventions for health care personnel in Swedish orthopaedic surgery departments. A national dialog may also be suggested in order to give equal and evidence based care to all persons in need of surgery. Nurses have a personal responsibility to contribute via lifelong learning and to maintain their professional competence (International Council of Nurses, 2012). We therefore suggest that specialist nurses in surgical care address this issue in their development programs.

Limitations in this study must be addressed. One potential limitation is the different professions represented in the study. The outcomes might have differed if only OR nurses had participated, as they have greater knowledge and advanced skills in aseptic and hygiene practice. Measure validity may also be discussed. In the preparation of this study, no validated instrument for measuring the knowledge and perception of skin preparation could be identified in the current literature. Hence, a questionnaire was constructed, which is not normally seen as a first choice (Polit and Beck, 2012).

A participant recruitment strategy was chosen based on the goal of including different professions that clinically perform skin preparation procedures. However, it is recommended in future research that all employees performing these procedures be recruited as participants. The sample in this study may be treated such that supervising nurses, matrons or head nurses acted as data gatekeepers who control the selection of respondents (Polit \& Beck, 2012). Future studies will include all employees working in that department. 


\section{Conclusion}

This study indicates the existence of skin preparation practices not based on evidence, a lack of knowledge and a misinterpretation of current guidelines, and clinical practice that lacks consensus at medical departments performing orthopaedic surgery in Sweden.

Further research is required in both the clinical benefits of skin preparation procedures and international investigations of current skin preparation procedures for comparison with this Swedish sample.

\section{Acknowledgement}

In remembrance and thankfulness to Dr. Mats Gullberg, who initiated and participated in the first part of this project, but swiftly and unexpectedly left us.

\section{Competing interests}

The authors declare that they have no competing interests and were free to interpret the data according to strict scientific rationale.

\section{Authors' contribution}

IM conceived the idea for the study. IM, Mats Gullberg and KB contributed to the design and concept. IM managed data collection. IM and KB analysed and interpreted the data, constructed and revised the manuscript for logical content and approved the final version. 


\section{References}

Association of Perioperative registered Nurses. (1996) Recommended practices for skin preparation of patients. AORN Journal, 75 (1), 184-187.

Boyce, J. M., \& Pittet, D. (2002). Guideline for hand hygiene in health-care settings: recommendations of the Healthcare Infection Control Practices Advisory Committee and the HICPAC/SHEA/APIC/IDSA Hand Hygiene Task Force. US Department of Health and Human Services. Centers for Disease Control and Prevention. Morbidity \& Mortality Weekly Report, 25(16), 1-45.

Brandberg, A. (1989). Preoperative wholebody disinfection (wiewpoint Sweden). Journal of Chemotherapy, 1, 19-24.

Darouiche, R. O. (2004) Treatment of infections associated with surgical implants. The New England Journal of Medicine, 350, 1422-1429.

De Lissovoy, G., Fraeman, K., Hutchins, V., Murphy, D., Song, D. \& .Vaughn, B. (2009) Surgical site infection: incidence and impact on hospital utilization and treatment costs. American Journal of Infection Control, 37, 387-397.

Derde, L. P., Dautzenberg, M. J., \& Bonten, M. J. ( 2012) Chlorhexidine body washing to control antimicrobial-resistant bacteria in intensive care units: a systematic review. Intensive Care Medicine, 38, 931-939.

Digison, M. B. (2007). A Review of Anti-septic Agents for Pre-operative Skin Preparation. Plastic Surgical Nursing, 27(4), 185-189.

Edmiston, C. E., Krepel, C. J., Seabrook, G. R., Lewis, B. R., Brown, K. R. \& Towne, J. B., (2008). Preoperative shower revisited: Can high topical antiseptic levels be achieved on the skin surface before surgical admission? Journal of American College of Surgeon, 207(2), 233239.

Edmiston, C. E., Okoli, O., Graham, M. B., Sinski, S., \& Seabrook, G. R. (2010). Evidence for using Chlorhexidine Gluconate preoperative cleansing to reduce the risk of surgical site infection. AORN journal, 92(5), 509-518.

Fresenius-Kabi (2014). Tvättinstruktion för Descutan ${ }^{\circledR}$ tvättsvamp. Retrieved from http://www.fresenius-kabi.se/Documents/Open\%20files/SE/Desinf/Descutanaffisch.pdf

Grabsch, E. A., Mitchell, D.J., Hooper, J., \& Turnidge, J. D. (2004) In-use efficacy of chlorhexidine in alcohol surgical rub: a comparative study. ANZ Journal of Surgery, 74(9), 769-772.

Hibbard, S., Mulberry, G. K., \& Brady, A. R. (2002). A clinical study comparing the skin antisepsis and safety of Chloro Prep, $70 \%$ isopropyl alcohol, and 2\% aqueous chlorhexidine. 
Journal of Infusion Nursing, 25, 244-249.

Hockenberry, M., Walden, M., Brown, T., \& Barrera, P. (2007). Creating an evidence based practice environment. Journal of Nursing Care, 22, (3), 222-231.

Humphreys, H. (2009). Preventing surgical site infection. Where are we now? Journal of Hospital Infection, 4 , 316-322.

International Council of Nurses (2012). Position statements: Patient safety. Retrieved from http://www.icn.ch/images/stories/documents/publications/position_statements/D05_Patient_S afety.pdf

Jenks, P. J., Laurent, M., McQuarry, S. \& Watkins, R. (2014) Clinical and economic burden of surgical site infection (SSI) and predicted financial consequences of elimination of SSI from an English hospital. Journal of Hospital Infection. 86(1), 24-33.

Johansson, M., \& Björk, H. (2011). En kartläggning om vårdpersonalens kunskap om basala hygienrutiner. (Master ), Linné Universitet, Retrieved februari, 12, 2013 from http://www.diva-portal.org/smash/get/diva2:430301/FULLTEXT02

Kamel, C., McGahan, L., Polisena, J., Mierzwinski-Urban, M., \& Embil, J. M. (2012). Preoperativeskin antiseptic preparations for preventing surgical site infections: a systematic review. Infection Control and Hospital Epidemiology, 33(6), 608-617.

Kaiser, A. B., Kernodle, D.S., Barg, N.L., \& Petracek, M.R. (1988) Influence of preoperative showers on staphylococcal skin colonization: a comparative trial of antiseptic skin cleansers. Annals of Thoracic Surgery, 45(1), 35-38.

Kirkland, K. B., Briggs, J. P., Triwett, S. L., Wilkingsson, W.E. \& Sexton, D.J. (1999). The impact of surgical site infections in the 1990's: attributable mortality, excess length of hospitalization and extra costs. Infection Control Hospital Epidemiology, 20: 725-730.

Klevens, R.M., Edwards, J. R., Richards, C. L., Horan, T.C., Gaynes, R. P., \& Pollock, D. A, et al. (2007)., 2002. Public Health Rep, 122(2), 160- 166.

Koburger, T., Hübner, N. O., Braun, M., Siebert. J., Kramer, A. (2010) Standardized comparison of antiseptic efficacy of triclosan, PVP-iodine, octenidine dihydrochloride, polyhexanide and chlorhexidine digluconate. Journal of Antimicrobial Chemotherapy, 65, 1712-1719.

Krizek, T., \& Robson, M. (1975). Biology of surgical infection. The Surgical clinics of North America, 55(6), 1261-1267.

Lilly, H. A., Lowbury, E. J., \& Wilkins, M. D. (1979). Limits to progressive reduction of resident skin bacteria by disinfection. Journal of Clinical Pathology, 32(4), 382-385.

Lowbury, E. J., Lilly, H. A. \& Bull, J. P. (1960) Disinfection of the skin of 
operation sites. British Medical Journal, 5205, 1039-1044.

Mangram, A. J., Horan, T. C., Pearson, M. L., Silver, L .C., \& Jarvis, W. R. (1999). Guideline for prevention of surgical site infection. Infection Control and Hospital Epidemiology, 20(4) $250-278$.

Mölnlycke health care (2013). Produktdatablad Hibiscrub®. Retrieved from http://www.molnlycke.com/knowledge/surgical-product-how-tos/how-preparesurgery-patient/

Pittet, D, Taraara, D., Wenzel, R. P. (1994) Nosocomial bloodstream infections in critically ill patients. Excess length of stay, extra costs, and attributable mortality. The Journal of the American Medical Association, 271, 1598-1601.

Polit, D. F., \& Beck, C. T. (2012). Nursing Research: Generating and assessing evidence for nursing practice ( sth $^{\text {ed.). }}$. Philadelphia Lippincott: Williams \& Wilkins.

Ponce-de-Leon, S. (1991) The needs of developing countries and the resources required. Journal of Hospital Infection, 18, 376-381.

Socialstyrelsen (2006) Att förebygga vårdrelaterade infektioner - ett kunskaps underlag. Lindesberg: Bergslagens grafiska. Retrieved from http://www.socialstyrelsen.se/publikationer2006/2006-123-12

Veiga, D. F., Joel Veiga-Filho, M., Ricardo Góes Figueiras, M., Roberto Bezerra Vieira, M., Edgard Silva Garcia, M., Silva, V. V., \& Ferreira, L. M. (2009). Randomized controlled trial of the effectiveness of chlorhexidine showers before elective plastic surgical procedures. INFECTION CONTROL AND HOSPITAL EPIDEMIOLOGY, 30(1), 77-79.

Voegeli, D. (2008) The effect of washing and drying practices on skin barrier function. Journal of Wound, Ostomy and Continence Nursing, 35(1), 84-90.

Webster, J. \& Osborne, S. (2006). Preoperative bathing or showering with skin antiseptics to prevent surgical site infection. The Cochrane Database of Systematics Reviews, 19(2), 1-44.

Whitehouse, J. D., Friedman, D., Kirkland, B., Richardson, W. J., \& Sexton, D. J. (2002) The impact of surgical site infections following orthopaedic surgery at a community hospital and a university hospital: adverse quality of life, excess length of stay and extra cost. Infection Control and Hospital Epidemiology, 23(4), 183-189.

World Health Organization. (2002). Prevention of hospital-acquired infections. A practical guide 2nd edition. Malta: Minimum graphics. Retrieved January,22, 2014. From http://www.who.int/csr/resources/publications/drugresist/en/whocdscsreph200212. pdf?ua $=1$ 